\title{
Language Needs Analysis of Iranian Undergraduate Students of Computer Engineering: A Study of Reading Skill
}

\author{
Alireza Fard-Kashani (Corresponding author) \\ Faculty of Arts and Education, University of Deakin, Melbourne, Australia \\ E-mail: afardkas@deakin.edu.au \\ Abdol Hossein Zahedi Jahromi \\ English Department, Alborz Institute of Higher Education, Qazvin, Iran
}

Ali Javadi

Foreign Languages Department, University of Science \& Technology, Tehran, Iran

Ali Mohammad Fallahi

Faculty of Foreign Languages and Literature, English Department, University of Kashan, Kashan, Iran

Doi:10.7575/aiac.alls.v.6n.5p.167

URL: http://dx.doi.org/10.7575/aiac.alls.v.6n.5p.167
Received: 08/05/2015

Accepted: 03/08/2015

\begin{abstract}
The current study aimed at diagnosing the language needs of Iranian undergraduate students of computer engineering in order to find out whether there is any significant difference in perceptions between the students and their ESAP (English for Specific Academic Purpose) teachers, concerning their Reading skill needs. To conduct the intended research study, both qualitative and quantitative approaches were taken. The quantitative approach included the use of self-assessment, and two questionnaires, and the qualitative approach included participant observation. The questionnaires were adapted from Atai and Shoja (2009), and were distributed among 500 undergraduate students of computer engineering and 30 ESAP teachers who were chosen randomly through cluster sampling method from thirteen universities. Mann-Whitney U-test results showed that there was a significant difference between perceptions of the students and their teachers about their Reading skill needs and 'Reading' was mentioned as one of the most difficult skills for the students. Moreover, it was found that the majority of students suffered from low level of General English Language Proficiency, and also 'low motivation' and the 'character' of teachers were found to be important factors affecting students' learning.
\end{abstract}

Keywords: Needs analysis, English for specific purposes, English for academic purposes, Present situation analysis, Target situation analysis

\section{Introduction}

Some scholars maintain that the study of Language for Specific Purposes (LSP) dates back to the Roman and Greek Empires (Dudley Evans \& St. John, 1998). According to Long (2005):

"In an era of shrinking resources, there are growing demands for accountability in public life, including education. In foreign and second language teaching, one of several consequences is the increasing importance attached to careful studies of learner needs as a prerequisite for effective course design" (p. 10).

As Hutchinson and Waters (1987) point out, “... any course should be based on an analysis of learner needs. This is one way in which ESP (English for Specific purposes) procedures can have a useful effect on General English and indicates once the need for a common approach" (pp. 53-54), and "A systematic and ongoing process of gathering information about students' linguistic needs and preferences, interpreting the information and then making course decisions in order to meet those needs" (Graves 2000, p. 74).

In non-English-speaking countries such as Iran, where English is used as a foreign language in academic and professional contexts, the need to design appropriate and to-the-point materials is highly crucial; so there must be a systematic and scientific plan arranged for the learners so that they would be able to reach their present and target needs. As literature shows, In Iran like many other countries, the need for ESP is expanding, and many researchers (e.g., Atai \& Khanjani, 2010; Atai \& Nazari, 2011; Atai \& Shoja, 2009; Dehghan, 2007) have examined language needs of learners; however, as Atai and Tahririan (2003) claim, although ESP programs are designed by the Ministry of Science, Research, and technology (MSRT) as a governmental organization responsible for the contents of academic books and contexts, the effectiveness of ESP courses and books was not so far seriously examined and studied. No serious needs analysis study have guided ESAP/EAP curriculum planning, course design, and text book development in Iran. In this 
line, the purpose of the current study was to take a big step in filling part of the existing gap by involving more than 500 participants from 13 universities in different cities; this helped the results to be more valid and representative of the intended population. Also, participant observation was conducted to meet data triangulation.

The following research questions were addressed in this descriptive study:

1. What are the Reading needs of Iranian undergraduate students of computer engineering?

2. What are the perceptions of ESAP teachers about Reading ability skills of Iranian undergraduate students of computer engineering?

3. Is there any significant difference between the perceptions of undergraduate students of computer engineering and ESAP teachers regarding their Present and Target language needs?

4. Is there any significant difference between perceptions of Iranian undergraduate students of computer engineering and their ESAP teachers concerning their Reading skill needs?

\section{Review of the Related Literature}

\subsection{English for Specific Purposes (ESP)}

Definitions of ESP

Hutchinson and Waters (1987) maintain that "ESP should properly be seen not as any particular language product but as an approach to language teaching which is directed by specific and apparent reasons for learning" (p.19). Also "it is an approach to language learning which is based on learner need. The foundation of all ESP is a simple question: Why does this leaner need to learn a foreign language?" (ibid: 19).

Dudley Evans and St. John (1998) emphasized two aspects of ESP methodology in their definition:

All ESP teaching should reflect the methodology of the disciplines and professions it serves; and in more specific ESP teaching the nature of the interaction between the teacher and the learner may be very different from that in a general English class. That is what we mean when we say that specific ESP teaching has its own methodology (Dudley Evans \& St. John, 1998: 4).

Robinson (1991) emphasizes that needs analysis is a primary step in defining ESP. Two key defining criteria and a number of characteristics are the basics of her definition that are broadly true about ESP. The criteria are that ESP is 'normally goal-directed', and that ESP courses develop from a needs analysis, which "aims to specify as closely as possible what exactly it is that students have to do through the medium of English" (Robinson, 1991:3). ESP courses are felt to be constrained by a limited time period in which their goals must be achieved and thought to adults that are in homogeneous classes as the work or studies that the students should be involved in.

\subsection{Needs Analysis}

According to Robinson (1991), "needs analysis is generally regarded as critical to ESP, although ESP is by no means the only educational enterprise which makes use of it" (p.7). Bachman and Palmer (1996) state that needs analysis is "the systematic gathering of specific information about the language needs of learners and the analysis of this information for purpose of language syllabus design" (p.102). Dudley Evans and St. John (1998) mention that needs analysis is the corner stone of ESP, it is unique to LSP and ESP, and leads to focused courses. "Needs analysis is the process of establishing the what and how of a course" (ibid: 121).

Dudley Evans and St. John (1998) stress three aspects of needs analysis as: "First, needs analysis aims to know learners as people, as language users and as language learners. Second, to know how language learning and skills learning can be maximized for a given learner group. Third, to know the target situations and learning environment so that data can appropriately be interpreted" (p.126). Richards (2001) defines needs analysis as "the procedures used to collect information about learners' needs" (p.51). Hutchinson and Waters (1987) argue that needs analysis should be the base of any course design. Robinson (1991) suggests that needs analysis study should be repeated so that it can be built into the formative process. Dudley-Evans and St John (1998), mention the main sources for needs analysis as: the learners, people dealing with the field, ex-students and documents relevant to the field, clients, employers, and ESP research in the field. Graves (1996) argues, although the term 'assessment' includes gathering data, and 'analysis' includes assigning value to the data, needs assessment and needs analysis are often used interchangeably.

Definitions of 'Need'

Long (2005) argues that no language course should be designed before identifying learners' needs. Berwick (1989) define needs as "a gap or measurable discrepancy between a current state of affairs and a desired future state"(p.52). According to this broad definition, different classifications of needs can be mentioned, Hutchinson and Waters (1987) divide needs into Target needs and learning needs, the former means "what the learner needs to do in the target situation" and the latter "means what the learner needs to do in order to learn" (p.54). 'Target needs' is a broad term, and include 'necessities', 'lacks', and 'wants' (ibid), they define 'necessities' as: "what the learner has to know in order to function effectively in the target situation"(p.55), knowing the current level of learner knowledge, one can decide which of the necessities he or she lacks (ibid).

Hutchinson and Waters (1987) present another classification in defining the concept of need that is objective needs and subjective needs, the former can be derived by outsiders from facts, and can be collected by questionnaires, personal interviews, data collection, observation, informal consultation with teachers and learners, and tests, while the latter can 
be analyzed from insiders from affective and cognitive factors and can be discovered through learner self-assessment using lists and scales, and questionnaires and interviews (ibid). According to Robinson (1991), goal-oriented and process-oriented are two other meanings discussed for the concept of needs. Goal-oriented definition refers to learners' job or study requirements, and process oriented definition refers to what learners need to do to learn the language (Widdowson, 1981).

\subsubsection{Two Approaches to Need Analysis}

Target Situation Analysis (TSA)

The term Target Situation Analysis (TSA) was first introduced by Chambers (1980). To him, "TSA is communication in target situation"(p.29). According to Hyland (2006), target situation analysis concerns mainly with objective and product oriented data. For Hutchinson and Waters (1987) the analysis of target situation needs is "in essence a matter of asking questions about the target situation and the attitudes towards that situation of various participants in the learning process" (p.59).

Munby (1978) presented a framework for TSA named 'Communicative needs processor' (CNP), in CNP, account is taken of "the variables that affect communication needs by organizing them as parameters in a dynamic relationship to each other" (p.32). It includes a range of variables affecting communication needs. The model has advantages and disadvantages, it has thorough databanks (Robinson 1991), but it is inflexible, time consuming, and complex (West, 1994), Hutchinson and Waters (1987) states that it does not considered the learning needs nor it makes a distinction between necessities, wants, and lacks.

Present Situation Analysis (PSA)

The term PSA (Present Situation Analysis) was first introduced by Richterich and Chancerel (1980). According to Robinson (1991), "PSA (Present Situation Analysis) seeks to establish what the students are like at the start of their language course, investigating their strengths and weaknesses" (p.8). In PSA, the sources of information are the students themselves, the teaching establishment, and the user-institution (Jordan, 1997). Dudley-Evans and St. John (1998) state "a PSA estimates strengths and weaknesses in language, skills, learning experiences"(p.125).

Munby (1978) argues that PSA represents constraints on the TSA. According to McDonough (1984), PSA involves 'fundamental variables', which must be clearly considered before the TSA. According to Jordan (1997), the learner is the center of the system surrounded by culture and society.

\subsubsection{Methodology of Needs Analysis}

Dudley-Evans and St. John (1998) suggest six main methods of data collection: Questionnaires, discussions, structural interviews, observation, assessment, and analysis of authentic spoken and written texts. Brown (1995) provides as many as twenty four methods, and then groups them into six main categories: Existing information, tests, observations, interviews, questionnaires and meeting. Jordan (1997) also includes instruments such as 'learner diaries' and 'selfassessment' in addition to the mentioned list. Inductive and deductive procedures are two other methods of data collection (Berwick, 1989). According to Richards (2001), different methods of needs analysis end in different results.

\section{Review of Empirical Researches on Needs Analysis}

Akyela and Ozeka (2010) carried out a needs analysis in an English medium university in Turkey. In this study the focus was basically on the importance and effective use of learning strategies related to four basic language skills in second or foreign language learning. Participants of the study included 2328 students in the 1st, 2nd, 3rd and 4th years of 6 different departments of 5 undergraduate and 1 graduate schools of the university, and 125 lecturers who were randomly selected from different departments in those schools. The results of the investigation indicated the need for encouragement of the students to use effective learning strategies in an English language education program of the Prep School. The results indicated no discrimination between teaching or testing in teaching materials and methods. This research study was a good example of needs analysis research using different methods of data analysis along with a large number of participants.

Wozniak (2010) set out a needs analysis that gives a detailed account of an analysis carried out at the French National Skiing and Mountaineering School. The aim was to assess the language needs of French mountain guides, the study started from August 2008 and continued to June 2009. The research consisted of three stages for the process of data gathering: first, three unstructured sixty-minute interviews which were conducted in August 2008, October 2008 and February 2009. Second, designing a questionnaire which included 37 questions and four parts: personal details (age, gender, mother tongue, and foreign languages), language biography (language training and travels). Also an open-ended question allowed candidates to contribute personal comments they considered relevant. Finally, information was gathered concerning novice guides' actual level of proficiency on graduation and the threshold of their careers (nonparticipant observation of the final exam). This triangulation procedure (by sources and methods) was used to strengthen the credibility and reliability of the results. The results showed that mountain guiding was a constantly evolving occupation, and many of guides believed that the main issue was improving communication skills not technical ones.

Rahman, Thang, Aziz, \& Abdul Razak (2009) aimed to investigate language needs to develop an ESP speaking course framework for the foreign postgraduates in the fields of science and technology at National University of Malaysia. According to results of the study, they mention the following: five foreign postgraduate students out of ten students faced difficulty in common oral presentations, three students indicated that their main problems were in pronunciation, 
these three students also stated that they faced difficulty in oral presentation (speaking) due to their shyness, three students did not find any difficulty in oral presentations in seminar/conference, one student indicated that she faced some difficulty in understanding local accent in English when she was pursuing her bachelor degree. As the final conclusion, Rahman et al. (2009) mentioned that course development should be an on-going process and designed courses should be evaluated and revisited repeatedly.

Another needs analysis study was designed by Dehghan (2007) aiming at finding language needs of electrical engineering and computer engineering undergraduate students in their carrier environment and academic setting. The participants of this study were 100 male and 58 female undergraduate students, 27 male and 3 female instructor, and 56 male and 19 female graduates. For data collection, questionnaire was used as the main source but to gather basic general information, 15 students were interviewed about 4 skills regarding their university studies and their future job environment. The findings stated that there was a significant difference between the perceptions of the undergraduate students, instructors, and college graduates regarding their language needs. It meant that the participants believed that different language needs were important for the students' success.

Moreover, Atai and Tahririan (2003) conducted a research study aiming at assessing the status of ESP in the Iranian Higher Education System. Participants of the study were 823 sophomores (males and females) who were enrolled in the corresponding EAP courses in the spring semester of the 1998-1999 academic years. They were discipline-based EAP university students majoring in medicine, dentistry, computer science, sociology, theology and Islamic sciences from 13 universities located in various parts of Iran. The results revealed that general English plays an influential role for success in EAP instruction. The Iranian EAP learners do not generally enjoy expected GEP levels prior to enrolment in EAP/ESP courses. The researchers seriously invited foreign language curriculum planners to diagnose mistakes in the curriculum and decide on appropriate remedial procedures.

\section{Method}

\subsection{Participants}

The participants of this study were two groups of undergraduate students of computer engineering, and ESAP teachers. The first group included 500 undergraduate students of computer engineering that were chosen randomly through cluster sampling method from 13 universities, namely: Industrial University of Babol, Khalij Fars University of Bushehr, University of Guilan, Bu-Ali-Sina University of Hamedan, University of Isfahan, Payam Noor University of Jahrom, ShahidBahonar University of Kerman, Payam Noor University of Evaz (Larestan), Ferdowsi University of Mashad, University of Qom, Islamic Azad University of Shiraz, University of Tehran, and University of Yazd. From this sample, 12 undergraduate students of computer engineering from 3 universities (Islamic Azad University of Shiraz, Payam Noor university of Jahrom, and Payam Noor University of Evaz (Larestan) were also selected through cluster sampling method in order to proofread the questionnaire for undergraduate students and comment on it.

Out of the 500 student participants, 463 ones returned the questionnaire, and 430 questionnaires were accurately completed and therefore usable for data analysis. The demographic profile of undergraduate students is presented in Table 1 below:

Table 1.The number and percent of male and female student participants

\begin{tabular}{ccc}
\hline Sex & Number & Percent \\
\hline Female & 162 & 37.7 \\
\hline Male & 268 & 62.3 \\
\hline Total & 430 & 100.0 \\
\hline
\end{tabular}

The other group of participants included 30 ESAP teachers (holding M.A or Ph.D.) from the above-mentioned universities selected randomly through cluster sampling method. Their teaching experiences ranged from 1 to 11 years. The details of their profiles are presented in Table 2.

Table 2. The number and percent of male and female ESAP teachers

\begin{tabular}{llll}
\hline Sex & & Number & Percent \\
\hline \multirow{2}{*}{} & Male & 23 & 76.7 \\
\cline { 2 - 4 } & Female & 7 & 23.3 \\
\cline { 2 - 4 } & Total & 30 & 100.0 \\
\hline
\end{tabular}

\subsection{Instrumentation}

In order to identify the Target and Present Situation of undergraduate students of computer engineering, both qualitative and quantitative approaches were triangulated in this study. The quantitative approach included self-assessment, and questionnaire and qualitative approach included participant observation. The following sections provide details of instrumentations utilized in this study. 
For the purpose of data collection, two questionnaires (one for undergraduate students of computer engineering and the other one for ESAP teachers) were developed. Developing the questionnaires comprised of various steps. The most important step was to determine the content of the questionnaires according to the criteria of questionnaire development mentioned in Dudley Evans and St. John (1998), Hutchinson and Waters (1987), and Jordan (1997). The main framework of questionnaires was adopted from Atai and Shoja (2009). Another step that was carefully accomplished before developing the questionnaires was to arrange a friendly interview with 12 undergraduate students of computer engineering at Islamic Azad University of Shiraz, Payame Noor University of Jahrom, and Payame Noor University of Evaz (Larestan). After developing the first draft of questionnaires, an ESP expert commented on the questionnaires, some of the items were edited and two open ended items were added at the end of each questionnaire. In order to find the probable problems with the questionnaires and to apply the students' and ESAP teachers' feedback to the final version of questionnaires, the questionnaires were piloted with 30 students and 10 ESAP teachers of the mentioned universities. Their oral suggestions as well as their notes in the questionnaires served as the sources of applying further modifications to make the final version of questionnaires more straightforward. In order to estimate the reliability of the final version of the questionnaires, they were administered to 30 undergraduate students of computer engineering and 5 ESAP instructors from three universities: Payam Noor University of Jahrom, Payam Noor University of Evaz (Larestan), and Islamic Azad University of Shiraz. Using Cronbach's Alpha Coefficient, the reliability of the questionnaires was estimated; the reliability indices were found to be 0.91 and 0.84 for the students' questionnaire and ESAP teachers', respectively, which were satisfactory and acceptable.

To sum up, the questionnaire developed for undergraduate students included four parts; the first part elicited demographic details including the name of university, semester of education, and gender of participants. The second part of the questionnaire was about learners' Present Situation, and asked the learners to assess themselves against 26 Likert-type self-assessment items regarding their current level of ability. The third part of the questionnaire included 27 Likert-type items asking the students about their views on the effect of the intended items in their educational progress, and in the fourth section of the questionnaire, three items were included.

The questionnaire developed for ESAP teachers, also, consisted of four parts. The first part addressed general information about the responder. The second part of the questionnaire included 22 Likert-type items asking the ESAP teacher to assess the current level of their students. The third part of this questionnaire addressed the Target language needs of students and included 20 Likert-type items on the importance of each item to the success of the students after their graduation. The last part of the questionnaire included three open-ended questions that required the ESAP teachers to write their comments.

\subsection{Procedure}

Aiming at analyzing Present and Target Reading needs of undergraduate students of computer engineering, two questionnaires for the two groups of participants (students and ESAP teachers) were taken from Atai and Shoja (2009). Using the comments of EAP/ESP experts, they were edited and then piloted to diagnose the probable mistakes, applying the last changes, the final version was prepared to be distributed among the participants. The questionnaires were administered to students and ESAP teachers of thirteen universities. Before running the questionnaires, the aims of the study were explained and students were made sure that their answers would be secure and anonymous. The data collection part was the most difficult part of this research, because the universities were chosen from different parts of Iran. As a part of our qualitative approach, participant observation was used in order to gather more exact and straightforward data. The undergraduate students' attitudes toward their ESAP teachers were asked by the researchers and in the case of enough free time, their problems and difficulties of studying in the field of computer engineering were talked about in a friendly and informal chat, also some notes were taken. The same procedure was done with ESAP instructors.

\section{Results and Discussion}

\subsection{Results of the undergraduate students' questionnaire: Answering the first research question}

In the second part of undergraduate students' questionnaire, Present Situation Needs Analysis (PSA), they were asked to assess their abilities against 26 Likert-type self-assessment items about their current level ability. The results are reported in Table 3 below:

Table 3. The undergraduate students' perceptions of PSA

\begin{tabular}{|c|c|c|c|c|c|c|c|c|c|c|c|}
\hline \multirow[t]{2}{*}{ Scale } & \multirow[t]{2}{*}{ Content Items } & \multicolumn{2}{|c|}{ Very much } & \multicolumn{2}{|c|}{$\begin{array}{l}\text { Less than very } \\
\text { much }\end{array}$} & \multicolumn{2}{|c|}{ A little } & \multicolumn{2}{|c|}{ Very little } & \multicolumn{2}{|c|}{ Near to zero } \\
\hline & & $\mathrm{F}$ & $\%$ & $\mathrm{~F}$ & $\%$ & $\mathrm{~F}$ & $\%$ & $\mathrm{~F}$ & $\%$ & $\mathrm{~F}$ & $\%$ \\
\hline 1 & $\begin{array}{l}\text { General vocabulary } \\
\text { knowledge }\end{array}$ & 30 & 7.0 & 182 & 32. & 168 & 39.1 & 50 & ${ }_{6}^{11 .}$ & 0 & 0.0 \\
\hline 2 & $\begin{array}{l}\text { Technical vocabulary } \\
\text { knowledge }\end{array}$ & 20 & 4.7 & 124 & ${ }^{28 .}$ & 194 & 45.1 & 92 & 21. & 0 & $\overline{0.0}$ \\
\hline
\end{tabular}




\begin{tabular}{|c|c|c|c|c|c|c|c|c|c|c|c|}
\hline 3 & $\begin{array}{l}\text { Understanding English } \\
\text { grammar and structure of } \\
\text { texts }\end{array}$ & 35 & 8.1 & 131 & $\begin{array}{l}30 . \\
5\end{array}$ & 186 & 43.3 & 78 & 18 & 0 & 0.0 \\
\hline 4 & $\begin{array}{l}\text { Understanding main } \\
\text { idea before details }\end{array}$ & 35 & 8.1 & 191 & $\begin{array}{l}44 . \\
4\end{array}$ & 149 & 34.7 & 55 & $\begin{array}{l}12 . \\
8\end{array}$ & 0 & 0.0 \\
\hline 5 & $\begin{array}{l}\text { Guessing the unfamiliar } \\
\text { words according to } \\
\text { neighboring words }\end{array}$ & 37 & 8.6 & 163 & $\begin{array}{l}37 . \\
9\end{array}$ & 172 & 40.0 & 57 & $\begin{array}{l}13 . \\
3\end{array}$ & 1 & 0.2 \\
\hline 6 & $\begin{array}{l}\text { Guessing the unfamiliar } \\
\text { words using prefixes and } \\
\text { suffixes }\end{array}$ & 28 & 6.5 & 129 & $\begin{array}{l}30 . \\
0\end{array}$ & 185 & 43.0 & 85 & $\begin{array}{l}19 . \\
8\end{array}$ & 3 & 0.7 \\
\hline 7 & $\begin{array}{l}\text { Using monolingual } \\
\text { general dictionary }\end{array}$ & 47 & 10.9 & 135 & $\begin{array}{l}31 . \\
4\end{array}$ & 136 & 31.6 & 110 & $\begin{array}{l}25 . \\
6\end{array}$ & 2 & 0.5 \\
\hline 8 & $\begin{array}{l}\text { Using monolingual } \\
\text { technical dictionary }\end{array}$ & 20 & 4.7 & 74 & $\begin{array}{l}17 . \\
2\end{array}$ & 144 & 33.5 & 185 & $\begin{array}{l}43 . \\
0\end{array}$ & 7 & 1.6 \\
\hline 9 & $\begin{array}{l}\text { Studying the themes of } \\
\text { previous sessions }\end{array}$ & 38 & 8.8 & 120 & $\begin{array}{l}27 . \\
9\end{array}$ & 170 & 39.5 & 82 & 19. & $0^{2}$ & 4.7 \\
\hline 10 & $\begin{array}{l}\text { Studying the themes of } \\
\text { each session after } \\
\text { finishing that session }\end{array}$ & 31 & 7.2 & 107 & $\begin{array}{l}24 . \\
9\end{array}$ & 165 & 38.4 & 90 & $\begin{array}{l}20 . \\
9\end{array}$ & $7^{3}$ & 8.6 \\
\hline 11 & $\begin{array}{l}\text { Studying the new themes } \\
\text { before each session }\end{array}$ & 18 & 4.2 & 86 & $\begin{array}{l}20 . \\
0\end{array}$ & 168 & 39.1 & 126 & $\begin{array}{l}29 . \\
3\end{array}$ & $2^{3}$ & 7.4 \\
\hline 12 & $\begin{array}{l}\text { Studying the original (not } \\
\text { translated) technical texts } \\
\text { and articles related to the } \\
\text { field }\end{array}$ & 34 & 7.9 & 82 & 19. & 138 & 32.1 & 111 & $\begin{array}{l}25 . \\
8\end{array}$ & $5^{6}$ & $\begin{array}{l}15 \\
1\end{array}$ \\
\hline 13 & $\begin{array}{l}\text { Translating the technical } \\
\text { texts and articles from } \\
\text { English to Persian }\end{array}$ & 25 & 5.8 & 85 & $\begin{array}{l}19 . \\
8\end{array}$ & 136 & 31.6 & 131 & $\begin{array}{l}30 . \\
5\end{array}$ & 3 & 3 \\
\hline 14 & $\begin{array}{l}\text { Search through the } \\
\text { internet for up to date and } \\
\text { original (not translated) } \\
\text { sources }\end{array}$ & 50 & 11.6 & 108 & $\begin{array}{l}25 . \\
1\end{array}$ & 138 & 32.1 & 100 & $\begin{array}{l}23 . \\
3\end{array}$ & $4^{3}$ & 7.9 \\
\hline 15 & $\begin{array}{l}\text { Establishing a technical } \\
\text { weblog in English to share } \\
\text { knowledge }\end{array}$ & 13 & 3.0 & 18 & 4.2 & 66 & 15.3 & 147 & $\begin{array}{l}34 . \\
2\end{array}$ & $86^{1}$ & $\begin{array}{l}43 \\
3\end{array}$ \\
\hline 16 & $\begin{array}{l}\text { Writing technical articles } \\
\text { in English }\end{array}$ & 7 & 1.6 & 11 & 2.6 & 48 & 11.2 & 16 & 3.7 & $48^{3}$ & $\begin{array}{l}80 \\
9 \\
\end{array}$ \\
\hline 17 & $\begin{array}{l}\text { Collecting educational } \\
\text { electronic files (like power } \\
\text { point files) in English }\end{array}$ & 20 & 4.7 & 45 & 5 & 104 & 24.2 & 157 & $\begin{array}{l}36 . \\
5\end{array}$ & $04^{1}$ & $\begin{array}{l}24 \\
2\end{array}$ \\
\hline 18 & $\begin{array}{l}\text { Using attractive and real } \\
\text { life texts }\end{array}$ & 38 & 8.8 & 130 & $\begin{array}{l}30 . \\
2\end{array}$ & 127 & 29.5 & 125 & $\begin{array}{l}29 . \\
1 \\
\end{array}$ & $0^{1}$ & 2.3 \\
\hline 19 & $\begin{array}{c}\text { Taking notes from } \\
\text { important parts (in class time } \\
\text { and when reading texts) }\end{array}$ & 162 & 37.7 & 161 & $\begin{array}{l}37 . \\
4\end{array}$ & 74 & 17.2 & 27 & 6.3 & 6 & 1.4 \\
\hline 20 & $\begin{array}{l}\text { Finding cause and effect } \\
\text { relationships when reading } \\
\text { related texts }\end{array}$ & 84 & 19.5 & 202 & $\begin{array}{l}47 . \\
0\end{array}$ & 101 & 23.5 & 29 & 6.7 & 4 & 3.3 \\
\hline 21 & Pouncing words exactly & 78 & 18.1 & 160 & $\begin{array}{l}37 . \\
2\end{array}$ & 149 & 34.7 & 38 & 8.8 & 5 & 1.2 \\
\hline 22 & $\begin{array}{l}\text { Memorizing the grammar } \\
\text { as formulas }\end{array}$ & 38 & 8.8 & 123 & $\begin{array}{l}28 . \\
6\end{array}$ & 165 & 38.4 & 91 & 21. & 3 & 3.0 \\
\hline 23 & $\begin{array}{l}\text { Learning the grammar } \\
\text { through examples and } \\
\text { exercise } \\
\end{array}$ & 79 & 18.4 & 167 & $\begin{array}{l}38 . \\
8\end{array}$ & 111 & 25.8 & 69 & $\begin{array}{l}16 . \\
0\end{array}$ & 4 & 0.9 \\
\hline 24 & $\begin{array}{l}\text { Contacting the professors } \\
\text { and other students by } \\
\text { sending English Emails }\end{array}$ & 18 & 4.2 & 41 & 9.5 & 81 & 18.8 & 180 & $\begin{array}{l}41 . \\
9\end{array}$ & 10 & $\begin{array}{l}25 \\
6\end{array}$ \\
\hline 25 & $\begin{array}{l}\text { Setting goals and aims for } \\
\text { my studying }\end{array}$ & 97 & 22.6 & 197 & $\begin{array}{l}45 . \\
8\end{array}$ & 93 & 21.6 & 41 & 9.5 & 2 & 0.5 \\
\hline 26 & $\begin{array}{c}\text { Setting plan and } \\
\text { framework for my studying }\end{array}$ & 63 & 14.7 & 175 & $\begin{array}{l}40 . \\
7\end{array}$ & 122 & 28.4 & 67 & $\begin{array}{l}15 . \\
6 \\
\end{array}$ & 3 & 0.7 \\
\hline
\end{tabular}

The third part of the undergraduate students' questionnaire included 27 Likert-type items. Students were asked about their opinion on the effect of the mentioned items in their educational progress. The results are reported below:

Table 4. The undergraduate students' perceptions of target situation needs

\begin{tabular}{|c|c|c|c|c|c|c|c|c|c|}
\hline \multirow{2}{*}{$\begin{array}{l}\text { Scale } \\
\text { Item }\end{array}$} & \multirow[t]{2}{*}{ Content Items } & \multicolumn{2}{|c|}{ Very important } & \multicolumn{2}{|c|}{ Important } & \multicolumn{2}{|c|}{$\begin{array}{l}\text { Somehow } \\
\text { important }\end{array}$} & \multicolumn{2}{|c|}{ Not important } \\
\hline & & $\mathrm{F}$ & $\%$ & $\mathrm{~F}$ & $\%$ & $\mathrm{~F}$ & $\%$ & $\bar{F}$ & $\%$ \\
\hline 1 & general vocabulary knowledge & 234 & 54.4 & 155 & 36.0 & 36 & 8.4 & 5 & 1.2 \\
\hline 2 & Technical vocabulary knowledge & 288 & 67.0 & 109 & 25.3 & 22 & 5.1 & 11 & 2.6 \\
\hline 3 & $\begin{array}{l}\text { Understanding English grammar and } \\
\text { structure of texts }\end{array}$ & 115 & 26.7 & 158 & 36.7 & 130 & 30.2 & 27 & 6.3 \\
\hline
\end{tabular}




\begin{tabular}{|c|c|c|c|c|c|c|c|c|c|}
\hline 4 & $\begin{array}{l}\text { Understanding main idea before } \\
\text { details }\end{array}$ & 137 & 31.9 & 185 & 43.0 & 93 & 21.6 & 15 & 3.5 \\
\hline 5 & $\begin{array}{l}\text { Guessing the unfamiliar words } \\
\text { according to neighboring words }\end{array}$ & 82 & 19.1 & 207 & 48.1 & 116 & 27.0 & 25 & 5.8 \\
\hline 6 & $\begin{array}{l}\text { Guessing the unfamiliar words using } \\
\text { prefixes and suffixes }\end{array}$ & 75 & 17.4 & 180 & 41.9 & 137 & 31.9 & 38 & 8.8 \\
\hline 7 & Using monolingual general dictionary & 103 & 24.0 & 156 & 36.3 & 129 & 30.0 & 42 & 9.8 \\
\hline 8 & $\begin{array}{l}\text { Using monolingual technical } \\
\text { dictionary }\end{array}$ & 128 & 29.8 & 165 & 38.4 & 103 & 24.0 & 34 & 7.9 \\
\hline 9 & $\begin{array}{l}\text { Studying the themes of previous } \\
\text { sessions }\end{array}$ & 147 & 34.2 & 183 & 42.6 & 82 & 19.1 & 18 & 4.2 \\
\hline 10 & $\begin{array}{l}\text { Studying the themes of each session } \\
\text { after finishing that session }\end{array}$ & 164 & 38.1 & 173 & 40.2 & 74 & 17.2 & 19 & 4.4 \\
\hline 11 & $\begin{array}{l}\text { Studying the new themes before each } \\
\text { session }\end{array}$ & 133 & 30.9 & 163 & 37.9 & 104 & 24.2 & 30 & 7.0 \\
\hline 12 & $\begin{array}{l}\text { Studying the original (not translated) } \\
\text { technical texts and articles related to the } \\
\text { Field }\end{array}$ & 154 & 35.8 & 160 & 37.2 & 90 & 20.9 & 26 & 6.0 \\
\hline 13 & $\begin{array}{l}\text { Translating the technical texts and } \\
\text { articles from English to Persian }\end{array}$ & 126 & 29.3 & 157 & 36.5 & 107 & 24.9 & 40 & 9.3 \\
\hline 14 & $\begin{array}{c}\text { Search through the internet for up to } \\
\text { date and original (not translated) sources }\end{array}$ & 167 & 38.8 & 159 & 37.0 & 78 & 18.1 & 26 & 6.0 \\
\hline 15 & $\begin{array}{l}\text { Establishing a technical weblog in } \\
\text { English to share knowledge }\end{array}$ & 92 & 21.4 & 119 & 27.7 & 127 & 29.5 & 92 & 21.4 \\
\hline 16 & Writing technical articles in English & 92 & 21.4 & 143 & 33.3 & 128 & 29.8 & 67 & 15.6 \\
\hline 17 & $\begin{array}{l}\text { Collecting educational electronic files } \\
\text { (like power point files) in English }\end{array}$ & 97 & 22.6 & 156 & 36.3 & 128 & 29.8 & 49 & 11.4 \\
\hline 18 & Using attractive and real life texts & 101 & 23.5 & 174 & 40.5 & 104 & 24.2 & 51 & 11.9 \\
\hline 19 & $\begin{array}{l}\text { Taking notes from important parts (in } \\
\text { class time and when reading texts) }\end{array}$ & 205 & 47.7 & 170 & 39.5 & 42 & 9.8 & 13 & 3.0 \\
\hline 20 & $\begin{array}{l}\text { Finding cause and effect relationships } \\
\text { when reading related texts }\end{array}$ & 133 & 30.9 & 177 & 41.2 & 95 & 22.1 & 25 & 5.8 \\
\hline 21 & $\begin{array}{l}\text { Exact and right pronunciation of } \\
\text { English words }\end{array}$ & 194 & 45.1 & 150 & 34.9 & 60 & 14.0 & 26 & 6.0 \\
\hline 22 & Memorizing the grammar as formulas & 67 & 15.6 & 155 & 36.0 & 132 & 30.7 & 76 & 17.7 \\
\hline 23 & $\begin{array}{l}\text { Learning the grammar through } \\
\text { examples and exercises }\end{array}$ & 155 & 36.0 & 173 & 40.2 & 84 & 19.5 & 18 & 4.2 \\
\hline 24 & $\begin{array}{l}\text { Contacting the professors and other } \\
\text { students by sending English Emails }\end{array}$ & 108 & 25.1 & 156 & 36.3 & 109 & 25.3 & 57 & 13.3 \\
\hline 25 & $\begin{array}{l}\text { Consulting with the learners after } \\
\text { introducing the resources for choosing } \\
\text { the best }\end{array}$ & 97 & 22.6 & 187 & 43.5 & 122 & 28.4 & 24 & 5.6 \\
\hline 26 & $\begin{array}{l}\text { Setting goals and aims for my } \\
\text { studying }\end{array}$ & 160 & 37.2 & 168 & 39.1 & 81 & 18.8 & 21 & 4.9 \\
\hline 27 & $\begin{array}{l}\text { Setting plan and framework for my } \\
\text { studying }\end{array}$ & 233 & 54.2 & 120 & 27.9 & 57 & 13.3 & 20 & 4.7 \\
\hline
\end{tabular}

The forth part of the undergraduate students' questionnaire included 3 items, one of them was a question about "the time a teacher allocates for solving the educational problems and answering students" and students can choose between 'less than enough' and 'enough'. More than 51 percent of the undergraduate students marked 'less than enough' as shown below:

Table 5. The time a teacher allocates for solving the educational problems

\begin{tabular}{ccc}
\hline Scale & Frequency & Valid Percent \\
\hline $\begin{array}{c}\text { less than } \\
\text { enough }\end{array}$ & 222 & 51.6 \\
\hline Enough & 208 & 48.4 \\
\hline Total & 430 & 100.0 \\
\hline
\end{tabular}

The other two items that were open-ended, let the respondents write first, what he or she thinks is better to do and what is better not to do in order to reach the desired level of reading skills, and the second item asked the responder to explain if he or she has any difficulty or objection about teaching methods, introduced recourses, and even classroom hours. 164 of questionnaires contained 291 suggestions and objections, they were categorized into 68 categories.

\subsection{Results of the ESAP teachers' questionnaire: Answering the second research question}

In the second part of ESAP teachers' questionnaire, Present Situation Needs Analysis (PSA), they were asked to assess undergraduate students' abilities against 22 Likert-type items. The results are reported below: 
Table 6. ESAP teachers' perceptions of PSA

\begin{tabular}{|c|c|c|c|c|c|c|c|c|c|c|c|}
\hline \multirow{2}{*}{$\begin{array}{l}\text { Scale } \\
\text { Item }\end{array}$} & \multirow[t]{2}{*}{ Content Items } & \multicolumn{2}{|c|}{ Very much } & \multicolumn{2}{|c|}{$\begin{array}{l}\text { Less than very } \\
\text { much }\end{array}$} & \multicolumn{2}{|c|}{ A little } & \multicolumn{2}{|c|}{ Very little } & \multicolumn{2}{|c|}{ Near to zero } \\
\hline & & $\mathrm{F}$ & $\%$ & $\mathrm{~F}$ & $\%$ & $\mathrm{~F}$ & $\%$ & $\mathrm{~F}$ & $\%$ & $\mathrm{~F}$ & $\%$ \\
\hline 1 & General vocabulary knowledge & 0 & 0.0 & 5 & $7^{16 .}$ & 21 & $\begin{array}{l}70 . \\
0\end{array}$ & 2 & 6.7 & 2 & 6.7 \\
\hline 2 & Technical vocabulary knowledge & 0 & 0.0 & 4 & 33. & 15 & $\begin{array}{l}50 . \\
0\end{array}$ & 10 & 33. & 1 & 3.3 \\
\hline 3 & $\begin{array}{l}\text { Guessing the unfamiliar words } \\
\text { according to neighboring Words }\end{array}$ & 2 & 6.7 & 10 & 33. & 14 & $\begin{array}{l}46 . \\
7\end{array}$ & 4 & 33. & 0 & 0.0 \\
\hline 4 & $\begin{array}{l}\text { Guessing the unfamiliar words } \\
\text { using prefixes and suffixes }\end{array}$ & 0 & 0.0 & 17 & 56. & 10 & 33. & 1 & 3.3 & 2 & 6.7 \\
\hline 5 & $\begin{array}{l}\text { Understanding the overall } \\
\text { meanings of simple daily } \\
\text { English dialogs }\end{array}$ & 2 & 6.7 & 10 & 33. & 17 & $\begin{array}{l}56 . \\
7\end{array}$ & 1 & 3.3 & 0 & 0.0 \\
\hline 6 & $\begin{array}{l}\text { Exact and correct pronunciation } \\
\text { of English words }\end{array}$ & 0 & 0.0 & 8 & 26. & 16 & 53. & 6 & $\begin{array}{l}20 . \\
0\end{array}$ & 0 & 0.0 \\
\hline 7 & $\begin{array}{l}\text { Understanding English grammar } \\
\text { and structure of texts }\end{array}$ & 0 & 0.0 & 12 & $\begin{array}{l}40 . \\
0\end{array}$ & 16 & 53. & 2 & 6.7 & 0 & 0.0 \\
\hline 8 & $\begin{array}{l}\text { Understanding main idea before } \\
\text { details }\end{array}$ & 1 & 3.3 & 16 & 33. & 11 & $\begin{array}{ll}36 . \\
7\end{array}$ & 2 & 6.7 & 0 & 0.0 \\
\hline 9 & $\begin{array}{l}\text { The ability to translate the } \\
\text { articles from English to Persian }\end{array}$ & 1 & 3.3 & 12 & $\begin{array}{l}40 . \\
0\end{array}$ & 15 & $\begin{array}{l}50 . \\
0\end{array}$ & 2 & 6.7 & 0 & 0.0 \\
\hline 10 & $\begin{array}{l}\text { Translating the articles from } \\
\text { English to Persian }\end{array}$ & 0 & 0.0 & 4 & 33. & 10 & 33. & 14 & $\begin{array}{l}46 . \\
7\end{array}$ & 2 & 6.7 \\
\hline 11 & $\begin{array}{l}\text { The ability to write official and } \\
\text { commercial letters }\end{array}$ & 1 & 3.3 & 8 & 26. & 12 & $\begin{array}{l}40 . \\
0\end{array}$ & 9 & $\begin{array}{l}30 . \\
0\end{array}$ & 0 & 0.0 \\
\hline 12 & $\begin{array}{l}\text { Search through the internet for } \\
\text { up to date and original (not } \\
\text { translated) sources }\end{array}$ & 0 & 0.0 & 2 & 6.7 & 15 & $\begin{array}{l}50 . \\
0\end{array}$ & 11 & $\begin{array}{l}36 . \\
7\end{array}$ & 2 & 6.7 \\
\hline 13 & $\begin{array}{l}\text { Writing technical articles in } \\
\text { English }\end{array}$ & 0 & 0.0 & 0 & 0.0 & 2 & 6.7 & 13 & $\begin{array}{ll}43 . \\
3\end{array}$ & 15 & 50. \\
\hline 14 & $\begin{array}{l}\text { Establishing a technical weblog } \\
\text { in English to share } \\
\text { Knowledge }\end{array}$ & 0 & 0.0 & 0 & 0.0 & 11 & $\begin{array}{l}36 . \\
7\end{array}$ & 16 & 53. & 3 & 10 . \\
\hline 15 & $\begin{array}{l}\text { Collecting educational electronic } \\
\text { files (like power point files) in } \\
\text { English }\end{array}$ & 0 & 0.0 & 1 & 3.3 & 14 & $\begin{array}{l}46 . \\
7\end{array}$ & 14 & $\begin{array}{l}46 . \\
7\end{array}$ & 1 & 3.3 \\
\hline 16 & $\begin{array}{l}\text { Memorizing the grammar as } \\
\text { formulas }\end{array}$ & 5 & 16 & 12 & $\begin{array}{l}40 . \\
0\end{array}$ & 11 & $\begin{array}{ll}36 . \\
7\end{array}$ & 2 & 6.7 & 0 & 0.0 \\
\hline 17 & $\begin{array}{l}\text { Learning the grammar through } \\
\text { examples and exercises }\end{array}$ & 1 & 3.3 & 11 & $\begin{array}{ll}36 . \\
7\end{array}$ & 11 & $\begin{array}{l}36 . \\
7\end{array}$ & 7 & $\begin{array}{ll}23 . \\
3\end{array}$ & 0 & 0.0 \\
\hline 18 & $\begin{array}{l}\text { Finding cause and effect } \\
\text { relationships when reading } \\
\text { related texts }\end{array}$ & 1 & 3.3 & 11 & $\begin{array}{l}36 . \\
7\end{array}$ & 14 & $\begin{array}{l}46 . \\
7\end{array}$ & 4 & 33 & 0 & 0.0 \\
\hline 19 & $\begin{array}{l}\text { Taking notes from important } \\
\text { parts (in class time and } \\
\text { when reading texts) }\end{array}$ & 14 & $\begin{array}{l}46 . \\
7\end{array}$ & 14 & $\begin{array}{l}46 . \\
7\end{array}$ & 2 & 6.7 & 0 & 0.0 & 0 & 0.0 \\
\hline 20 & $\begin{array}{l}\text { Looking forward to work in } \\
\text { small or large groups }\end{array}$ & 7 & 23. & 15 & $\begin{array}{ll}50 . \\
0\end{array}$ & 6 & $\begin{array}{l}20 . \\
0\end{array}$ & 2 & 6.7 & 0 & 0.0 \\
\hline 21 & $\begin{array}{l}\text { Setting goals and aims for my } \\
\text { studying }\end{array}$ & 2 & 6.7 & 10 & $\begin{array}{ll}33 . \\
3\end{array}$ & 14 & $\begin{array}{l}46 . \\
7\end{array}$ & 4 & $3^{13 .}$ & 0 & 0.0 \\
\hline 22 & $\begin{array}{l}\text { Setting plan and framework for } \\
\text { my studying }\end{array}$ & 0 & 0.0 & 9 & $\begin{array}{l}30 . \\
0\end{array}$ & 14 & $\begin{array}{l}46 . \\
7\end{array}$ & 7 & 23. & 0 & 0.0 \\
\hline
\end{tabular}

The next part of the ESAP teachers' questionnaire aimed at dealing with the Target Situation Needs of students, it included 18 Likert-type items about the importance of each item on the success of the students after their graduation, the items had 4 levels: Very Important, Somehow Important, not Very Important, and not Important.

The details are dealt with below:

Table 7. ESAP teachers' perceptions of target situation needs

\begin{tabular}{|c|c|c|c|c|c|c|c|c|c|}
\hline \multirow{2}{*}{$\begin{array}{l}\text { scale } \\
\text { Item }\end{array}$} & \multirow{2}{*}{ Content Items } & \multicolumn{2}{|c|}{ Very important } & \multicolumn{2}{|c|}{ Important } & \multicolumn{2}{|c|}{$\begin{array}{l}\text { Somehow } \\
\text { important }\end{array}$} & \multicolumn{2}{|c|}{ Not important } \\
\hline & & $\mathrm{F}$ & $\%$ & $\mathrm{~F}$ & $\%$ & $\mathrm{~F}$ & $\%$ & $\mathrm{~F}$ & $\%$ \\
\hline 1 & General vocabulary knowledge & 16 & 53.3 & 0 & 0.0 & 14 & 46.7 & 0 & 0.0 \\
\hline 2 & Technical vocabulary knowledge & 18 & 60.0 & 12 & 40.0 & 0 & 0.0 & 0 & 0.0 \\
\hline 3 & $\begin{array}{l}\text { Guessing the unfamiliar words } \\
\text { according to neighboring }\end{array}$ & 15 & 50.0 & 13 & 43.3 & 2 & 6.7 & 0 & 0.0 \\
\hline 4 & $\begin{array}{l}\text { Guessing the unfamiliar words using } \\
\text { prefixes and suffixes }\end{array}$ & 17 & 56.7 & 13 & 43.3 & 0 & 0.0 & 0 & 0.0 \\
\hline 5 & $\begin{array}{l}\text { Understanding the overall meanings of } \\
\text { simple daily English dialogs }\end{array}$ & 13 & 43.3 & 16 & 53.3 & 1 & 3.3 & 0 & 0.0 \\
\hline
\end{tabular}




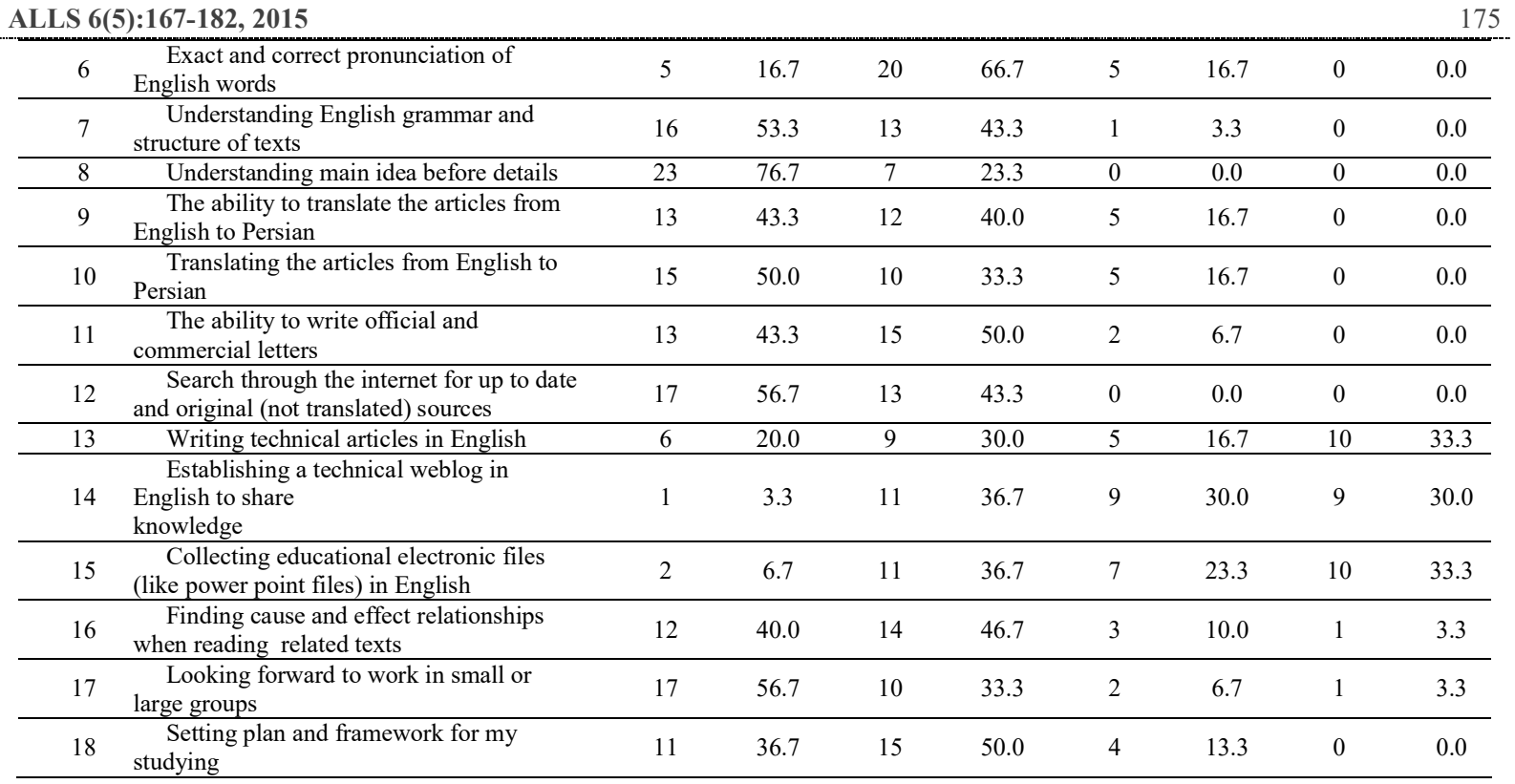

As mentioned before, the last part of this questionnaire included 3 open ended questions that let the ESAP teacher write his or her comment(s). They are: "what do you think of the current level of general English of your students?, explain about the probable weaknesses.", "if you have any limitation in your teaching (time, resources, or even improper time of English classes) that you think affects the success of students, please explain it.", and "is there any emphasis on group and team work in your introduced recourses? In either case please explain the reason."

24 out of 30 ESAP questionnaires contained answers of these 3 items, for the first item "what do you think of the current level of general English of your students? Explain about the probable weaknesses", 24 comments were left.

\subsection{Results of Mann-Whitney U-tests: Answering the third and the fourth research questions}

To answer the third research question about any difference between the perceptions of Iranian undergraduate students of computer engineering and ESAP teachers regarding their Present and Target language needs, a Mann-Whitney U test was conducted as below:

Table 8. Results of Mann-Whitney U-test for participants' perceptions concerning their reading skill needs

\begin{tabular}{|c|c|c|c|c|}
\hline & Groups & $\mathrm{N}$ & Mean Rank & Sum of Ranks \\
\hline \multirow[t]{3}{*}{ PSA } & Students & 430 & 240.32 & 103338.50 \\
\hline & Teachers & 30 & 89.72 & 2691.50 \\
\hline & Total & 460 & & \\
\hline \multirow[t]{3}{*}{ TSA } & Students & 430 & 245.18 & 105426.50 \\
\hline & Teachers & 30 & 20.12 & 603.50 \\
\hline & Total & 460 & & \\
\hline
\end{tabular}

Table 9. Results of Mann-Whitney U-test for participants' perceptions concerning their present and target language needs

\begin{tabular}{lcc}
\hline & PSA & TSA \\
\hline Mann-Whitney U & $2.226 \mathrm{E} 3$ & 138.500 \\
\hline Wilcoxon W & $2.692 \mathrm{E} 3$ & 603.500 \\
\hline Z & -6.002 & -8.969 \\
\hline Asymp. Sig. (2-tailed) & .000 & .000 \\
\hline
\end{tabular}

Table 9.illustrates a significant difference concerning the above mentioned factor $(\mathrm{p}=.000<.05)$; in other words, there is a significant difference between the perceptions of Iranian undergraduate students of computer engineering and ESAP teachers regarding their present and target language needs.

In order to answer the fourth research question, asking for any significant difference between perceptions of Iranian undergraduate students of computer engineering and their ESAP teachers concerning their Reading skill needs, the items of the questionnaires that assessed the Reading ability of students were separated (items number: A1, A2, A4, A5, A6, A12, A15, A20, A24, B1, B2, B4, B5, B6, B12, B15, B16, B17, B20, and B24 in the students' questionnaire and 
items number: A1, A2, A3, A4, A5, A8, A18, B1, B2, B3, B4, B5, B8, and B16 in the ESAP teachers' questionnaire), and another Mann-Whitney U-test was conducted:

Table 10. Results of Mann-Whitney U-test for the difference between perceptions of Iranian undergraduate students of computer engineering and their ESAP teachers concerning their reading skill needs: group statistics

\begin{tabular}{rlrrr}
\hline & Groups & N & Mean Rank & Sum of Ranks \\
\hline \multirow{2}{*}{ Reading Scores } & Students & 430 & 244.67 & 105206.00 \\
\cline { 2 - 5 } & Teachers & 30 & 27.47 & 824.00 \\
\cline { 2 - 5 } & Total & 460 & & \\
\hline
\end{tabular}

Table 11. Results of Mann-Whitney U test for the difference between perceptions of Iranian undergraduate students of computer engineering and their ESAP teachers concerning their reading skill needs: Test statistics

\begin{tabular}{cc}
\hline & Reading Scores \\
\hline Mann-Whitney U & 359.000 \\
\hline Wilcoxon W & 824.000 \\
\hline$Z$ & -8.654 \\
\hline Asymp. Sig. (2-tailed) & .000 \\
\hline
\end{tabular}

According to the obtained results $(\mathrm{p}=.00<.05)$, there is a significant difference between the perceptions of Iranian undergraduate students of computer engineering and their ESAP teachers concerning their reading skill needs.

\section{Discussion}

12.19 percent of students believed that 'time' of English classes were not enough; 11.58 percent believed that English should be taught from earlier educational levels, 10.37 percent believed that 'motivation' was low, and the same percent believe that English classes should be held in morning sessions, 9.76 percent believed that students were not involved with the materials, and the same percent believed that English laboratory was not used, 8.54 percent believed that teachers should introduce up-to-date and original English resources, 7.32 percent believed that "we don't ask teachers to teach, just not hinder our learning", 6.71 believed that English classes should be run as a conversation class, 6.10 percent believed that ESAP teachers did not have knowledge about teaching material, 4.88 percent believed that In English classes teachers should speak and teach in L2, 3.66 percent believed in more emphasis on pronunciation, speaking, and reading, the same percent believed that English courses should be presented in all semesters and years of academic educations, English classes were crowded, teachers should categorize the related words and teach them together, and more emphasis should be paid on grammar, 2.44 percent believed that more emphasis should be paid on vocabulary, the same percent believed that more emphasis should be paid on reading comprehension, 1.83 percent believed that English classes should be learner-centered, the same percent believed that teaching methods in High school and university are exactly the same, and class environment was not calm and silent, 1.22 percent believed that teachers should have kind and respectable characters, the same percent believed that teacher should oblige the students to present an article or a lecture, new words should be taught in readings, teachers did not try to solve the ambiguities of the students, teaching methods were too old, teachers did not pay any attention to teaching and the only important issue were marks and scores, teachers came to class with long delays, sessions were very near and this lead to boredom, English classes should be held in evening sessions, 0.61 percent believed that using technical texts instead of general ones were more helpful, the same percent believed English lessons had no aims, English should be divided into two parts: speaking and writing, reviewing the previous chapters and parts were necessary, more attention should be paid to cause and effect relationship when teaching, unfamiliar word guessing was not taught, teachers pay more attention only to limited students not all of them, teachers should oblige the students to do some homework, introduced materials were not usable at all, learning was limited to class time, technical key terms should be used and introduced in introduced materials, introducing useful internet sites were necessary, more attention should be paid to translation, teaching new words using synonyms was very useful, no emphasis was on listening, grammar was taught deductively, teachers invited students to his/her private classes, technical English courses should not be presented before helping the students with their low level of English proficiency, using flash cards were very useful, teachers should present an abstract of new materials before going to details, teachers should let the students evaluate the teaching methods, problem solving sessions were necessary, teachers used marks and scores as a gun, teachers should teach not read aloud from the introduced books. It is worth mentioning that 2.44 percent of students believed that everything was ok and no need was necessary.

59 percent of ESAP teachers believed that undergraduate students of computer engineering suffered from low General English Proficiency, it was in line with Atai's (2002) findings. ESAP teachers mentioned 'writing', 'reading', 'and speaking' as the most difficult skills for students, also some of them mentioned 'pronunciation' as difficult as speaking for students. About 30 percent of ESAP teachers believed that students also suffer from low inner motivation because they assume that their weak base of English cannot be changed.

For the next item "if you have any limitation in your teaching (time, resources, or even improper time of English classes) that you think affects the success of students, please explain it", majority of ESAP teachers mentioned that 
improper time of English classes together with crowded classes and inadequate time of classes were important factors that did not let them choose a good method of teaching, also some of them mentioned that up-to-date and useful resources were not available for students and even for ESAP teachers themselves.

And finally the last but not the least item "is there any emphasis on group and team work in your introduced recourses? In either case please explain the reason" the answers were nearly half and half 'Yes' and 'No', the reasons for those that their answer was 'Yes' were: group work help learners learn much in a less time span, it helps them learn from each other, it also imposes less stress to them. But on the other hand, the other half believed that because it was not conventional to do a job in a group in our culture and learners did not learn how to handle a group, in addition to lack of time and crowded English classes, it would not work. The findings of this research were in accordance with the results obtained by Atai (2000) who claimed that GEP level of students was not satisfactory.

To sum up, the present results reveals that students' GEP level are low, they are bored and demotivated, they have not internalized reading skills, teaching methods are old, and resources are not up-to-date; The results of this study corroborate the findings of a number of previous studies that claim that most EAP/ESP courses are unsatisfactory in addressing students' needs (e.g., Moattarian \& Tahririan, 2014; Atai \& Asadi, 2013; Amirian \& Tavakoli, 2009). So, ESAP teachers, syllabus designers and people in charge must pay more attention to the importance of needs analysis, because the results show that ESP programs for students of computer engineering are not developed according to learners' Target and Present academic needs. Such inconsistency found between academic instruction and students' needs is in line with findings of Atai and Tahririan (2003) and also Dominguez and Rokowski (2005).

\section{Conclusions and Implications}

Based on the findings of the current study, many students believed that ESAP teachers did not try to make the atmosphere of class live and motivating, participants also complained about outdated and boring resources, it is a good idea that English teachers introduce new materials and even electronic resources, using real life materials and asking the students to bring the materials that they think will be useful and enjoyable is a worthy opinion. Some students complained about the long delays of teachers (sometimes up to 20 minutes) before coming to class. Some other believed that ESAP teachers should be knowledgeable about the subject of that he/she wants to teach and only English language knowledge would not be enough. A number of students asked the teachers to emphasize reading comprehension as well as speaking and pronunciation. As many students complained and most of teachers agreed, the classes are more teachercentered, and it is the teacher that mainly speaks, students wanted to hold the classes more learner-centered, they wanted the teacher to be as a guide and director of teaching not the only authority in the class. Some students complained about the attitudes of teachers in the class and revealed that some teachers use scores and negative points as a punishment, they mentioned that the character of a teacher will affect the students' character too. ESAP teachers should pay more attention to the importance of English courses in Iran, the results of this study can help them with their teaching. Moreover, some of the comments asked the teachers to teach the reading skills first and then going through it, they believed that many students don't know the skills related to reading, and they just start reading from top to bottom without understanding even the main idea. When it came to group work, students believed that many teachers hate group works because they can't control the atmosphere, students believed that if teachers first explains about the aims and usefulness of group works and also the procedure, students will benefit from group work and learn from each other, students believed that most of times introducing a group work in a class is a mean teachers use to waste time.

The results of this study revealed that students should take their English courses more serious and pay for it. The most important issue about the students is their low Level of English Proficiency, the students themselves should study harder to compensate for their lacks and ask the teachers to introduce basic resources for their free study. Many teachers mentioned that although students know that their GEP level is low, but they do nothing to treat this educational illness. Inner low motivation is another issue that ESAP teachers talked about, they believed that many students have no aim when coming to English classes, students should highlight their aims and goals then they should pay for it to reach the optimum level. Teachers asked the students not to look at English classes as old habit. Some teachers talked about the students as blood in the educational system vessels, they asked the students to work harder on their English Proficiency Level to make the educational system healthy.

\section{References}

Akyela, A. S., \& Ozeka, Y. (2010). A language needs analysis research at an English medium university in Turkey. Procedia Social and Behavioral Sciences, 2, 969-975.

Amirian, Z., \& Tavakoli, M. (2009). Reassessing the ESP courses offered to Engineering students in Iran (A Case Study). English for Specific Purposes World, 8(23). Retrieved March 25, 2014, from http://www.espworld.info/Articles_23/manuscript.\%20ESP\%20World.pdf

Atai, M. R. (2000). ESP revisited: A reappraisal study of discipline-based EAP in Iran. Unpublished doctoral dissertation, University of Esfahan, Esfahan, Iran.

Atai, M. R. (2002). ESAP curriculum planning in Iran: An incoherent educational experience. Special Issue of the Journal of Persian Literature and Human Sciences of Tehran Teacher Training University, 1, 17-34. 
Atai, M. R., \& Khanjani, A. (2010). An operational profile of the present and target needs of Iranian ESAP students of science. Paper presented at The Second Conference of the Asia-Pacific Rim: Languages for Specific Purposes and Professional Communication. University of Malaya, Kuala Lumpur, Malaysia.

Atai, M. R., \& Nazari, O. (2011). Exploring reading comprehension needs of Iranian EAP students of Health Information Management (HIM): A triangulated perspective. System, 39(1), 30-43.

Atai, M. R., \& Shoja, L. (2009, August). Academic language needs of Iranian undergraduate students of computer engineering: A triangulated perspective. Paper presented at XVII Symposium on Languages for Specific Purposes: Methods and Aims. University of Aarhus, Aarhus, Denmark.

Atai, M. R., \& Tahririan, M. H. (2003). Assessment of the status of ESP in the current Iranian higher educational system. Proceedings of the 14th European Symposium on Language for Special Purposes: Communication, culture, and knowledge. University of Surrey, Guildford, UK.

Atai, M. R., \& Asadi, S. A. (2013). Assessing academic and professional English language needs of Iranian railway engineering students: A triangulated evaluation study. ESP Across Cultures, 10, 35-54.

Bachman, L. F., \& Palmer, A. S. (1996). Language Testing in Practice. Oxford: Oxford University Press.

Berwick, R. (1989). Needs assessment in language programming: From theory to practice. In R. K. Johnson (Ed.), The Second Language Curriculum, (pp. 48-62). Cambridge: Cambridge University Press.

Brown, J. D. (1995). The elements of language curriculum: A systematic approach to program development. Boston: Heinle \& Heinle.

Chambers, F. (1980). A re-evaluation of needs analysis in ESP. The ESP Journal, 1(1), 25-33.

Dehghan, N. (2007). Needs analysis of electrical engineering and computer engineering undergraduate students in academic setting and work environment. Unpublished master's thesis, Iran University of Science and Technology, Tehran, Iran.

Dominguez, G. A., \& Rokowski, P. E. (2005). Bridging the gap between English for academic and occupational purposes. ESP World. Retrieved March 19, 2014, from

http://www.espworld.info/Articles_2/Bridging\%20the\%20gap $\% 20$ between $\% 20$ English $\% 20$ for $\% 20$ Academic $\% 20$ and $\%$ 20Occupational\%20Purposes.html

Dudely-Evans, T., \& St. John, M. (1998). Developments in English for Specific Purposes. Cambridge: Cambridge University Press.

Graves, K. (1996). A framework of course development process. In J. C. Richards (Ed.), Teachers as course developers, (pp. 12-38). Cambridge: Cambridge University Press.

Graves, K. (1996). Teachers as Course Developers. Cambridge: Cambridge University Press.

Graves, K. (2000). Designing language course: A guide for teachers. USA: Heinle \& Heinle.

Hutchinson, T., \& Waters. A. (1987). English for Specific Purposes: A learning-centered approach. Cambridge: Cambridge University Press.

Jordan, R. R. (1997). English for Academic Purposes. Cambridge: Cambridge University Press.

Long, M. H. (2005). Second language needs analysis. Cambridge: Cambridge University Press.

McDonough, J. (1984). ESP in perspective: A practical guide. London: Collins.

Moattarian, A., \& Tahririan, M. H. (2014). Language needs of graduate students and ESP courses: The case of tourism management in Iran. RALs, 5(2), 4-22.

Munby, J. (1978). Communicative syllabus design. Cambridge: Cambridge University Press.

Rahman, M. M., Thang, S. M., Aziz, M. S. A., \& Abdul Razak, N. (2009). Developing an ESP speaking course framework for the foreign postgraduates in science and technology at national university of Malaysia. The Asian ESP Journal, 5(2). 1-57.

Richards. J. C. (2001). Curriculum development in language teaching. Cambridge: Cambridge University Press.

Richterich, R., \& Chancerel, J. L. (1980). Identifying the needs of adults learning a foreign language. Oxford: Pergamon Press.

Robinson, P. (1991). ESP today: A practitioner's guide. London: Prentice Hall.

West, R. (1994). Needs analysis in language teaching. Language Teaching, 27, 1-19.

Widdowson, H. G. (1981). English for Specific Purposes: Criteria for course design. In Sinkler, L., Tarone, E. \& Hanzeli, V. (Eds.). English for Academic and Technical Purposes: Studies in honor on Louse Trimble, Rowley, MA. Newbury House. 1-11.

Wozniak, S. (2010). Language needs analysis from a perspective of international professional mobility: The case of French mountain guides. English for Specific Purposes. 29, 243-252. 


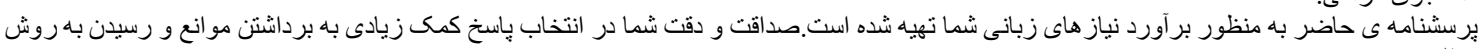

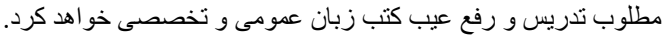
با تشكر

1-خيلى زياد 2-زياد 3- كم 4-خيلى كم 5-اصلا

در اين بخش لطفا وضعيت فعلى خود را در موارد آمده ذكر كنيد

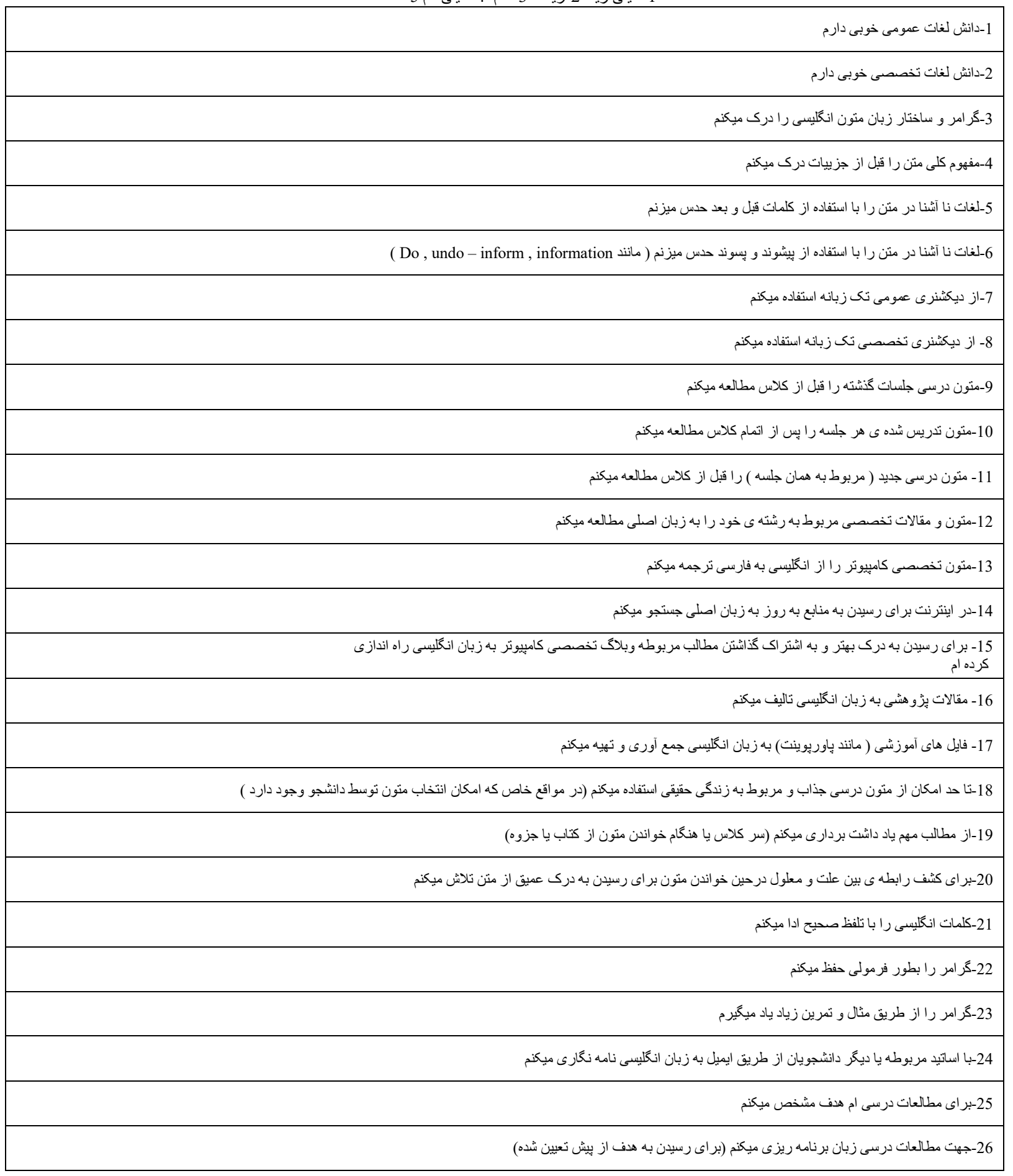




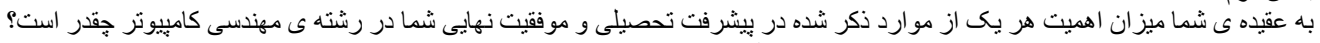

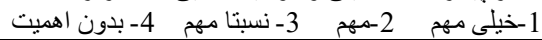

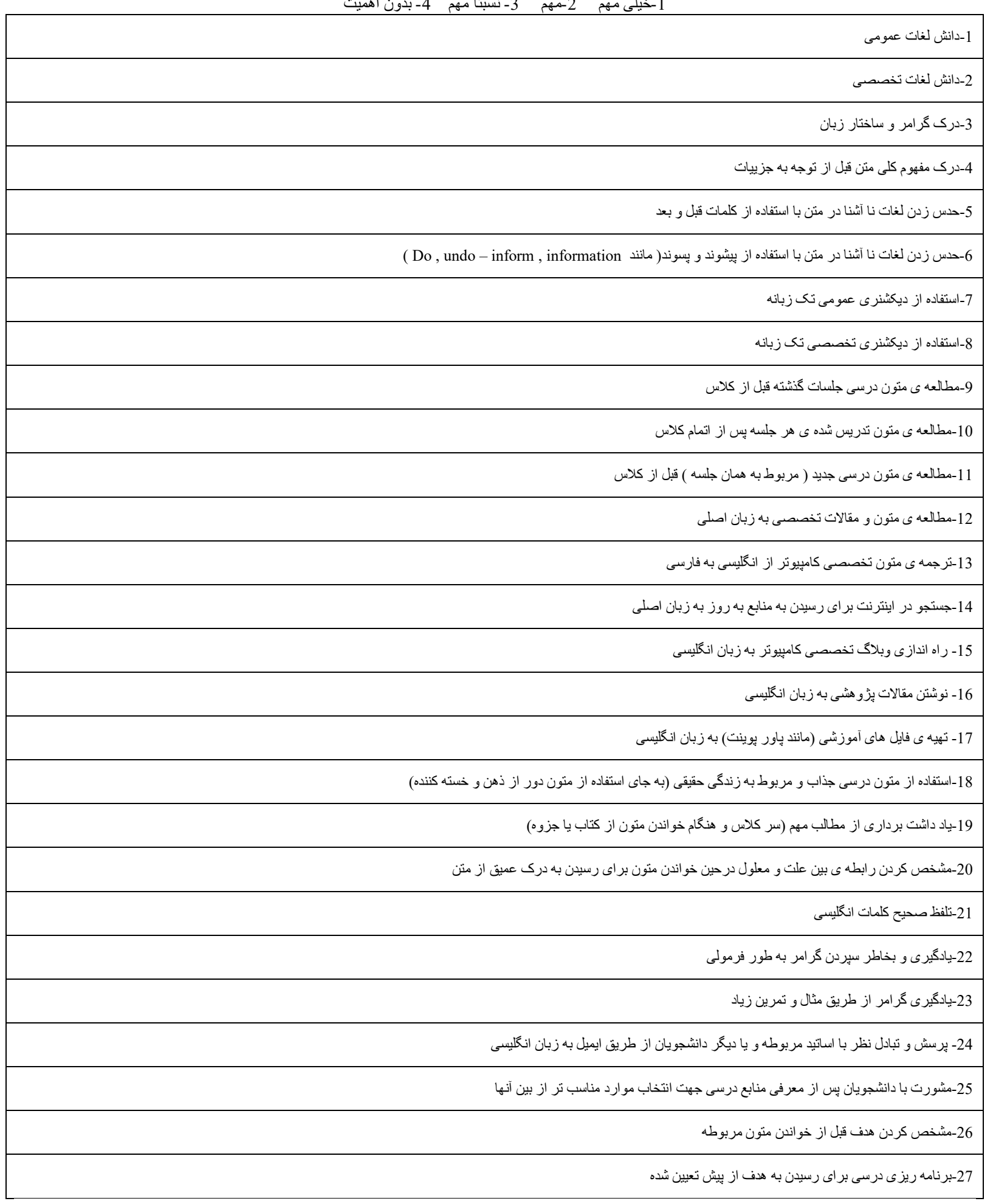




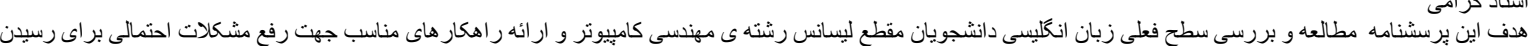

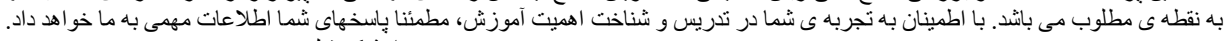

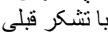

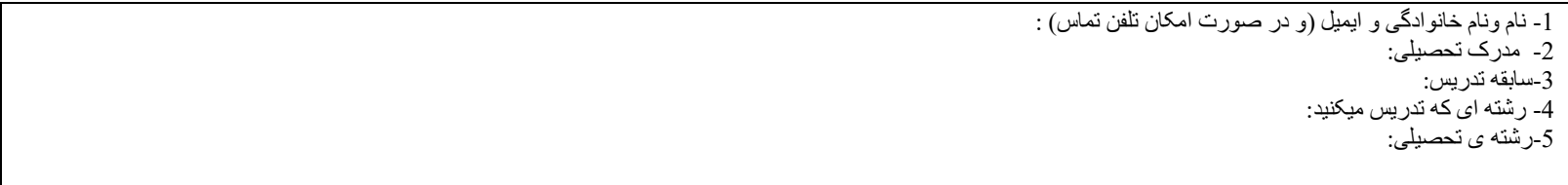

بها عقيده ى شما سطح فعلى دانشجويان در هر كدام از موارد زير در جه حدى است؟ 1- خيلى قوى 2- قوى 3- منوسط 4-ضعيف

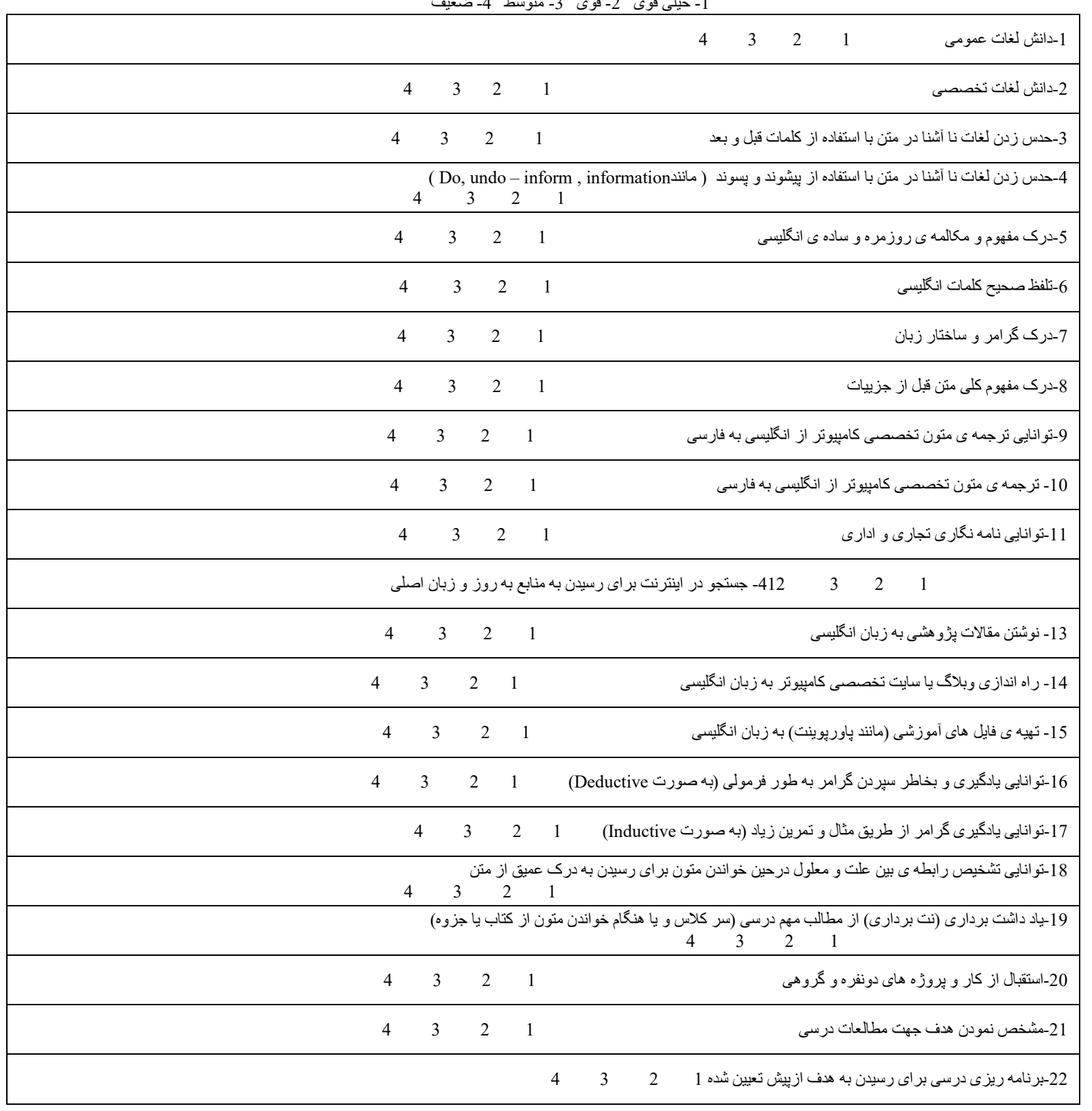

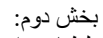
لطفا ميز ان اهميت هر يك از مهارتهاى زبانى زير را در موفقيت حرفه اى دانثجويان بعد از فارغ التحصيل شدن تعيين كنيد.

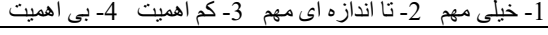

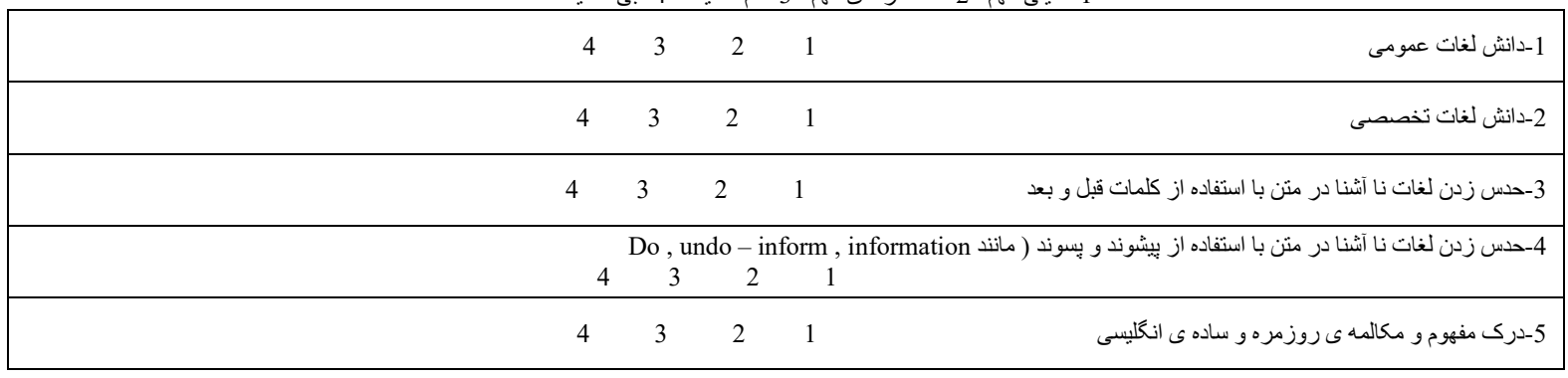




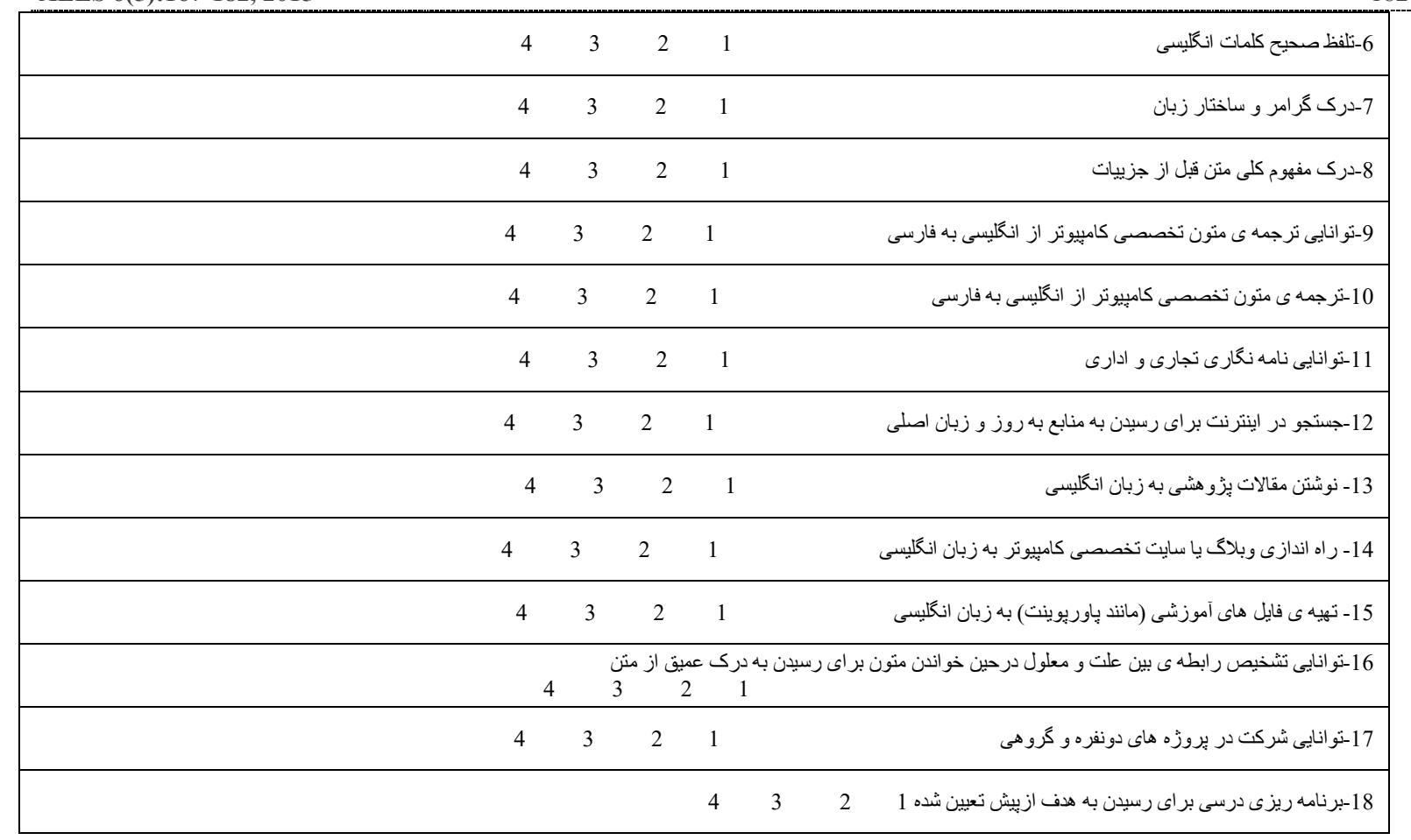

1- به عقوم: شى شما سطح فعلى زبان انكليبى عمومى دانثجويانتان در جه حدى است؟ لطفا نقاط ضعف احتمالى را بيان كنيد

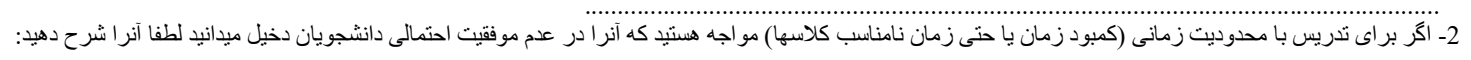

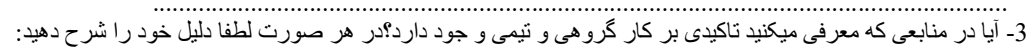
. 